\title{
Systemic inflammation and alteration in vitamin D levels in pregnancy induced hypertension
}

\author{
Dilutpal Sharma', Rahul Saxena', Raj Saxena², Mousumi Sharma ${ }^{3}$, Alok Milton Lal ${ }^{4}$ \\ ${ }^{1}$ Department of Biochemistry, SMSR, Sharda Hospital, Sharda University, Greater Noida, U.P, India, ${ }^{2}$ Department of Clinical Research, \\ Sikkim Manipal University, Manipal, India, ${ }^{3}$ Department of Pathology, Dr. B.B.C.I., Guwahati, Assam, India, ${ }^{4}$ Department of Biochemistry \& \\ Biochemical Engineering, Jacob School of Biotechnology \& Bioengineering, SHIATS, Allahabad, U.P, India
}

\section{A B S TR A C T}

Background: The increasing incidence of Pregnancy induced hypertension (PIH) or Preeclampsia in developed and developing countries are alarming. Systemic inflammation and disturbances in vitamin D and minerals (Sodium \& Calcium) metabolism are almost invariable consequences of $\mathrm{PIH}$; and variation in their levels can adversely affect the pregnancy leading to the development of PIH. Aim: In this context, a study was carried out to assess the level of serum vitamin D, sodium, calcium and inflammatory marker C-reactive protein (CRP) in non-pregnant (NP), normotensive pregnant (NTP) and PIH women and to determine their role in the etio-pathogenesis of PIH. Material and method: Serum vitamin D, sodium, calcium and CRP levels were estimated in 20 NTP women (Group I) and 20 PIH women (Group II) by using standard methods and statistically compared it with that of age matched 20 healthy non pregnant women (Control group) by using student's t-test. Result: Serum $\mathrm{Ca}^{++}$level were found to be significantly low in both Group I $(p<0.05)$ and Group II $(p<0.01)$ as compared to healthy controls. However, plasma vitamin D levels were decreased insignificantly in Group I $(p<0.1)$ and significantly $(p<0.05)$ in Group II patients. Similarly, serum sodium and CRP levels were increased significantly only in Group II patients. Conclusion: Thus, regular assessment of serum CRP, vitamin D, sodium and calcium levels and recommendation of diet low in sodium, rich in calcium and appropriate vitamin $D$ should be increased during pregnancy to prevent $\mathrm{PIH}$ and its related complications.

Key words: $25-\mathrm{OH}$ cholecalceferol, calcium, Parathormone, sodium, c-reactive protein
Access this article online

Website:

http://nepjol.info/index.php/AJMS

\section{INTRODUCTION}

Preeclampsia is an important cause of maternal and parental morbidity and mortality, with essentially unknown etiology. Its symptoms include hypertension, proteinuria and associated endothelial dysfunction. ${ }^{1}$ Several researches are going on to find out the relation between altered nutrient metabolism \& its related complications in pregnant women. Vitamin D, an important nutrient for growth and bone health, helps in maintaining calcium homeostasis and regulating parathyroid secretion and bone calcium mobilization as well. ${ }^{2}$ In previous studies, vitamin D has been found to be effective in improving immunity, endothelial dysfunction and nitric oxide availability, and reducing atherosclerotic parameters. Vitamin D modulates contraction, inflammation and remodeling tissue. Its beneficial effects in cell differentiation, muscle strengthening and in prevention of age related complications, have also been documented. ${ }^{3,4}$ In addition, low levels of vitamin D have also been found to be associated with gestational diabetes and risk of hypertension. ${ }^{5}$ However, the relationship between altered vitamin $\mathrm{D}$ status and incidence of pre-eclampsia in developing countries has yet not been fully elucidated.

Occurrence of systemic inflammation also exerts deleterious effect in increasing the complexity and development of hypertension during pregnancy. C-reactive protein (CRP), a sensitive index of overall inflammatory activity in the body, is also found to be 
elevated in acute infections, malignancy and inflammatory diseases. ${ }^{6}$ In addition, role of CRP in opsonisation and phagocytosis of apoptotic cells via its binding with chromatin and small nuclear ribonucleoprotein particles has been reported. ${ }^{7}$ Moreover, assessment of serum CRP levels in pre-eclamsia patients in relation with altered vitamin $\mathrm{D}$ status is scarce.

Amongst various different minerals, Sodium and Calcium are the most abundant cations in the extracellular fluid (ECF) and plays a significant role in maintenance of homeostasis by participating in various physiological activities such as neuromuscular irritability, nerve conduction, cardiac contractility, vascular smooth muscle proliferation, vasodilation, blood coagulation, in proper functioning of enzymes which include $\mathrm{Ca}^{2+}$-ATPase, enzymes of carbohydrate and fatty acid metabolism; cell division, calcification of bones and teeth and in the prevention of development of obesity and hypertension etc. $^{8}$ Altered level of these elements may induce series of events and adversely affect the pregnancy which inturn leads to the development of PIH. Early recognition may help the women to receive treatment and prevent the development of PIH and its related complications. Therefore, the overall objective of present study was to estimate serum vitamin $\mathrm{D}$, sodium and calcium levels along with marker of systemic inflammation CRP in normotensive pregnant (NTP) and hypertensive pregnant women (PIH) and to determine their relation in the development of hypertension during pregnancy.

\section{MATERIALS \& METHODS}

In the present study, 20 NTP women \& 20 subjects of PIH were taken in study group i.e. Group I and Group II respectively and 20 age matched NP women were taken in control group.

\section{Inclusion criteria}

The pregnant women having blood pressure greater than $140 / 90 \mathrm{~mm} \mathrm{Hg}$ diagnosed after 20 weeks of gestation with evidence of proteinuria $(\sim 200 \mathrm{mg} / \mathrm{l})$ and fulfilled National Institute for Health and Clinical Excellence (NICE) guidelines 107, were grouped as PIH subjects (Group II). A general information or pre-experimental questionnaire regarding anthropometric and clinical data was completed from all the patients after taking their informed consent and approval of protocol by ethics committee of college.

\section{Exclusion criteria}

Patients with diabetes mellitus, family history of hypertension, smoking habit, renal insufficiency, hepatic disease, obese (BMI > 30), taking lipid lowering drugs, diuretics or vitamin and minerals supplements were excluded.

Fasting blood samples were collected in a plane vial from each subjects followed by serum separation after measurement of blood pressure and recognition of other symptoms of PIH i.e. proteinuria, edema and sudden weight gain etc. In addition, PIH subjects and pregnant women with other systemic diseases were excluded from the study. Estimation of serum vitamin D (25-OH cholecalceferol) was done in VITROS EciQ immunodiagnostic system by chemiluminescence method. Serum C-reactive protein levels were measured using commercially available ELISA kits (R\&D Systems, USA), according to manufacturer's instructions. Serum sodium $\left(\mathrm{Na}^{+}\right)$levels were measured by Sinha method by using flame photometer in which test sample is aspirated followed by calculation of test sample value from calibration curve of standard solution (i.e. $\mathrm{NaCl}$ solution). ' Serum calcium levels were estimated by Tinder's method. Calcium in an alkaline medium combines with o-Cresolphthalein Complexone to form a purple coloured complex, which is measured at $570 \mathrm{~nm} .{ }^{10}$

\section{Statistical analysis}

Values were expressed as Mean \pm SD. The significance of mean difference between groups was compared by using Student's ' $t$ '-test. Linear regression analysis and Pearson correlation test were performed to determine the association between above said indexes or parameters.

\section{RESULTS}

In the present study, demographic profile of the study group subjects is depicted in Table 1. Blood pressure measurement revealed significant elevation in Group II subjects with respect to Group I and control which indicates their direct relation with disease process. Marked alteration in the levels of serum vitamin D, CRP, sodium and calcium were observed in the study group subjects, as represented in Table 2. Serum vitamin D levels were decreased significantly only $(\mathrm{p}<0.05 ; 28.23 \%$ low $)$ in Group II patients while insignificant decline $(p<0.1)$ observed in Group I subjects $(14.11 \%$ low) as compared to controls. On the other hand, serum calcium levels were found to be

\begin{tabular}{|c|c|c|c|c|}
\hline S. No. & Particulars & $\begin{array}{c}\text { Control group } \\
(n=20)\end{array}$ & $\begin{array}{c}\text { Group I } \\
(n=20)\end{array}$ & $\begin{array}{c}\text { Group II } \\
(n=20)\end{array}$ \\
\hline 1. & Age (years) & $27.3 \pm 2.6$ & $29.4 \pm 3.1$ & $31.1 \pm 2.5$ \\
\hline 2. & $\begin{array}{l}\text { Systolic blood } \\
\text { pressure }(\mathrm{mmHg})\end{array}$ & $112 \pm 4.0$ & $124 \pm 4.8$ & $148 \pm 6.0$ \\
\hline 3. & $\begin{array}{l}\text { Diastolic blood } \\
\text { pressure }(\mathrm{mmHg})\end{array}$ & $74.0 \pm 2.5$ & $82 \pm 3.0$ & $96 \pm 4.0$ \\
\hline
\end{tabular}

Asian Journal of Medical Sciences | Oct-Dec 2014 | Vol 5 | Issue 4 
decreased significantly ( $<<0.05 \& \mathrm{p}<0.001)$ in both Group I (NTP women) and Group II (PIH women) subjects i.e. $20.43 \%$ and $39.04 \%$ low respectively, as compared to controls but these values do not differ significantly in Group I and Group II. Serum sodium and CRP levels were also found to be increased significantly $(\mathrm{p}<0.05)$ only in Group II subjects (i.e. $14.72 \%$ \& $43.8 \%$ high respectively) whereas these levels were altered insignificantly $(p<0.1)$ in Group I as compared to controls. Correlation coefficient ( $\mathrm{r}$ ) between Blood Pressure (BP) and various markers (vitamin, minerals and systemic inflammation) in PIH subjects (Table 3) reflect the association of hypertension with alteration in vitamin $\mathrm{D}$ status, minerals $\left(\mathrm{Na}^{+} \& \mathrm{Ca}^{2+}\right)$ and marker of systemic inflammation (CRP) levels and their effect in disease pathology. Similarly, reduction in vitamin $\mathrm{D}$ level was inversely related with hypernatremia and CRP levels whereas positively correlated with hypocalcemia in PIH subjects (Table 4).

\section{DISCUSSION}

Pre-eclampsia, a form of high blood pressure in pregnancy, is an important cause of maternal and perinatal mortality affecting $5-7 \%$ of all pregnancies. ${ }^{2}$ It has now been proved that disturbances in vitamins

\begin{tabular}{|c|c|c|c|c|}
\hline S. No. & Particulars & $\begin{array}{l}\text { Control } \\
\text { group } \\
(n=20)\end{array}$ & $\begin{array}{c}\begin{array}{c}\text { Group I } \\
(n=20)\end{array}\end{array}$ & $\begin{array}{c}\text { Group II } \\
(n=20)\end{array}$ \\
\hline 1. & Calcium (mg/dl) & $9.35 \pm 0.69$ & $7.44 \pm 0.30^{\star *}$ & $5.70 \pm 0.38^{* *}$ \\
\hline 2. & Vitamin D (ng/ml) & $31.6 \pm 2.08$ & $27.14 \pm 1.43^{*}$ & $22.68 \pm 1.99^{* *}$ \\
\hline 3. & Sodium (meq/L) & $138.2 \pm 2.24$ & $145.25 \pm 2.35^{\star}$ & $158.55 \pm 2.48^{* *}$ \\
\hline 4. & $\mathrm{CRP}(\mathrm{mg} / \mathrm{L})$ & $2.85 \pm 0.25$ & $3.28 \pm 0.15^{\star}$ & $4.10 \pm 0.27^{* *}$ \\
\hline
\end{tabular}

\begin{tabular}{|c|c|c|c|c|}
\hline Particulars & $\begin{array}{l}\text { CRP level } \\
\text { (Group II) }\end{array}$ & $\begin{array}{c}\text { Calcium } \\
\text { level } \\
\text { (Group II) }\end{array}$ & $\begin{array}{c}\text { Sodium } \\
\text { level } \\
\text { (Group II) }\end{array}$ & $\begin{array}{l}\text { Vitamin } \\
\text { D level } \\
\text { (Group II) }\end{array}$ \\
\hline $\begin{array}{l}\text { Blood } \\
\text { pressure }\end{array}$ & +0.375 & -0.541 & +0.620 & -0.438 \\
\hline
\end{tabular}

Table 4: Correlation coefficient ( $r$ ) between
serum vitamin D and other parameters (serum
CRP, Calcium and sodium) in PIH subjects
\begin{tabular}{lccc} 
Particulars & $\begin{array}{c}\text { Serum } \\
\text { CRP level } \\
\text { (Group II) }\end{array}$ & $\begin{array}{c}\text { Serum } \\
\text { calcium level } \\
\text { (Group II) }\end{array}$ & $\begin{array}{c}\text { Serum } \\
\text { sodium level } \\
\text { (Group II) }\end{array}$ \\
\hline Serum vitamin D & -0.347 & +0.462 & -0.305 \\
\hline
\end{tabular}

and minerals metabolism play a significant role in the genesis of hypertension. ${ }^{11}$ Increased serum sodium and enhanced activity of the rennin angiotensin system (RAS) are well known contributor of hypertension. In addition, vitamin $\mathrm{D}$ acts as a proximal inhibitor of RAS activity. ${ }^{3}$ In previous animal study on mice lacking vitamin $\mathrm{D}$ receptor and deficient in $1 \alpha$-hydroxylase activity revealed enhanced plasma renin activity with development of hypertension. ${ }^{12}$ In the present study, serum vitamin D levels were found to significantly low in PIH patients and inversely associated with serum sodium levels which indicate that deficiency of vitamin $\mathrm{D}$ and increased serum sodium levels are responsible for increased RAS activity and thereby development of pre-eclampsia during pregnancy. These findings were also in concordance with the recent findings of Wei et al and Mangereeka respectively. ${ }^{13,14}$ However, salt induced elevation in vitamin $\mathrm{D}$ and no role of sodium restriction in the management of pre-eclampsia have been documented.

Previous observational and experimental studies have showed an association between inflammation, endothelial dysfunction and cardiovascular complications. ${ }^{15,16}$ In addition, maternal inflammatory response to pregnancy plays a crucial role in the etiology of endothelial dysfunction leading to pre-eclampsia. Further, it has been observed and reviewed that $1,25\left(\mathrm{OH}_{2}\right) \mathrm{D}$ act as a vascular protective agent by improving endothelial dysfunction and reduces inflammatory indexes. ${ }^{17,} 18$ Therefore, reduction in $1,25\left(\mathrm{OH}_{2}\right) \mathrm{D}$ levels have been implicated in the induction of inflammation followed by pre-eclampsia. Similarly, in the present study, serum CRP levels were also found to be elevated and inversely co-related with serum vitamin D levels in PIH patients which reflects the possible role of vitamin D deficiency mediated elevation of systemic inflammation and thereby its pathological consequence. Nanda et al in their study also observed elevated CRP levels in pre-eclampsia patients and highlighted its role in the etiopathogenesis of pre-eclampsia. ${ }^{7}$

Calcium homeostasis has long been associated with blood pressure regulation and it has been reported that alteration in serum calcium concentration plays a significant role in hypertension. ${ }^{3,8}$ In the present study, serum calcium level in normotensive and hypertensive pregnant women were significantly low $(p<0.05)$ as compared to controls. Decreased level of serum calcium in pregnant women was mainly due to maternal demand of calcium necessary for faetal bone mineralisation and inadequate absorption due to vitamin D deficiency. ${ }^{5}$ Recently, Mangereeka showed a close and inverse relationship of serum calcium concentration and pregnancy induced hypertension. ${ }^{14}$ 
Moreover, Parathyroid harmone (PTH), serve as the primary regulator of blood ionized calcium, plays an important role in the pathogenesis of hypertension. Mangreeka also suggested that during pregnancy decreased level of $\mathrm{Ca}^{++}$in E.C.F. elevates the PTH level which increases the intracellular calcium in vascular smooth cells and initiate vasoconstriction, which inturn leads to high blood pressure. ${ }^{14}$ Similarly, an inverse relationship between serum calcium level with increase in blood pressure also observed in the present study (Table 3). Anderson and Agarwal also documented that elevated PTH level in hypertensive subjects leads to defect in renal calcium handling by affecting kidneys. Thus, decreased serum $\mathrm{Ca}^{++}$ level in pregnancy provokes PTH secretion which reduces calcium excretion in urine by enhancing calcium reabsorption in the distal nephron but as the blood pressure increases continuously, it affects the renal function leading to increase in urinary calcium excretion with successive reduction in serum calcium level. ${ }^{19}$ Although serum calcium level has been found to be closely associated with pre-eclampsia, however, the largest trial to date showed no effect of calcium supplementation on pre-eclampsia. ${ }^{20}$

\section{CONCLUSION}

On the basis of present findings and consistent findings of previous studies, we concluded that decrease in serum vitamin $\mathrm{D}$ and altered levels of sodium and calcium in pregnant women are associated with increase in blood pressure and play a significant role in the etiopathogenesis of PIH. Thus, assessment of inflammatory markers along with vitamin $\mathrm{D}$ status serves as an important diagnostic tool in early detection of PIH development. In addition, reduction in serum calcium occurs not only due to maternal demand of calcium necessary for fetal bone mineralization and inadequate absorption due to vitamin $\mathrm{D}$ deficiency but also due to hypernatremia and vitamin D deficiency mediated high PTH level leading to intracellular elevation of calcium level and thereby induction of hypertension. However, further studies on vitamin and minerals supplementation are needed to explore the hidden facts related to disease pathology and to overcome the incidence of PIH. Moreover, the present evidence is strong enough to have convinced nutritionists and gynecologists that daily consumption of low fat dairy products, fruits and vegetables rich in calcium should be increased along with enhanced exposure to sunlight and adequate vitamin $\mathrm{D}$ supplement during pregnancy, not only to prevent the incidence of PIH but also to boost the maternal health and fetal growth as well.

\section{REFERENCES}

1. Gifford RW, August PA, Cunningham G, Green LA, Green LA, Lindheimer MD, et.al. Report of the National High Blood pressure Education Program working group of High Blood pressure in Pregnancy. Am J Obstet Gynecol 2000, 183: S1-S22.

2. Ramma $W$ and Ahmed $A$. Is inflammation the cause of preeclampsia. Biochem Soc Trans 2011; 39: 1619-1627.

3. Vaidya A and Forman JP. Vitamin D and hypertension- Current evidence and future directions. Hypertension 2010; 56: 774-779.

4. Shaik-Dasthagirisaheb YB, Varvara G, Murmura G, Saggini $A$, Caraffa A, Antinolfi $P$, et al. Role of vitamins $D, E$ and $C$ in immunity and inflammation. J Biol Regul Homeost Agents 2013; 27(2):291-295.

5. Fischer PR, Rahman A, Cimma JP, Kyaw-Myint TO, Kabir AR, Talukder K, et al. Nutritional rickets without vitamin $\mathrm{D}$ deficiency in Bangladesh. J Trop Pediatr 1999; 45(5): 291-293.

6. Bhattacharya I, Saxena R and Gupta V. Efficacy of vitamin E in knee osteoarthritis management of North Indian geriatric population. Ther Adv Musculoskel Dis 2012; 4(1): 11-19.

7. Nanda K, Sadanand G, Krishna M and Mahdevappa KL. C-reactive protein as a predictive factor of pre-eclampsia. Int $\mathrm{J}$ Biol Med Res 2012; 3(1):1307-1310.

8. Saxena R and Lal AM. Culprit effect of altered total antioxidant status and lipid peroxidation mediated electrolyte imbalance on Ageing. J Indian Acad Geriat 2007; 3 (4): 137-144.

9. Sinha SN. Determination of serum sodium and potassium. Practical Chemical Pathology $1^{\text {st }}$ ed., Sahitya Bhandar, Allahabad. 1986; p. 118.

10. Trinder P. Estimation of Serum calcium level. Analyst 1960; 85 : 889-891.

11. Gupta V, Saxena R, Bhattacharya I, Thakur RK and Mishra M. Lipid peroxidation mediated electrolyte imbalance and altered antioxidant status in Hypertensive smokers. Saudi Germ Hosp Med J 2011; 5(1): 7-17.

12. Zhou C, Lu F, Cao K, Xu D, Goltzman D and Miao D. Calciumindependent and $1,25(\mathrm{OH})_{2} \mathrm{D}_{3}$-dependent regulation of the reninangiotensin system in 1a-hydroxylase knockout mice. Kidney Int 2008; 74: 170-179.

13. Wei SQ, Audibert F, Hidiroglou N, Sarafin K, Julien P, Wu P, et al. Longitudinal vitamin $D$ status in pregnancy and the risk of preeclampsia. BJOG 2012; 119 (7): 832-839.

14. Manjareeka M, Nanda S. Serum electrolyte levels in preeclamptic women: a comparative study. Int J Pharma and BioSciences 2012; 3(2): 572-578.

15. Zimmerman GA, Prescott SM and McIntyre TM. Endothelial cell interactions with granulocytes: tethering and signaling molecules. Immunol Today 1992; 13: 93-100.

16. Saxena R, Bhattacharya I and Saxena R. Susceptibility of Knee Osteoarthritic patients to develop Cardiovascular disease. Asian J Medical Sciences. 2013; 4(3): 62-68.

17. Talmor Y, Golan E, Benchetrit S, Bernheim J, Klein O, Green $\mathrm{J}$, et al. Calcitriol blunts the deleterious impact of advanced glycation end products on endothelial cells. Am J Physiol Renal Physiol. 2008; 294: F1059-F1064.

18. Sung CC, Liao MT, Lu KC and Wu CC. Role of Vitamin D in Insulin Resistance. J Biomed Biotechnol 2012; 2012: 634195.

19. Anderson MJ and Agarwal R. Etiology and management of hypertension in chronic kidney disease. Med Clin North Am 2005; 89: 525-547.

20. Levine RJ, Hauth JC, Curet LB, Sibai BM, Catalano PM, Morris $\mathrm{CD}$, et al. Trial of calcium to prevent preeclampsia. N Engl J Med 1997; 337(2):69-76. 
Authors Contribution:

DS - principal investigator, formulation of study, facilitate the sample collection; RS - biochemical analysis, data collection and writing of manuscript; RS - planning, evaluation and literature collection; $\mathbf{M S}$ - statistical analysis, literature collection; AML - correction of the write up \& manuscript editing.

Source of Support: Nil, Conflict of Interest: None declared. 